\title{
FLEXIBLE DISCRETE MATH OFFLINE TEST GENERATOR
}

\author{
Kurdubov S. L. ${ }^{1}$, PhD, senior researcher, kurdubov@iaaras.ru \\ Kurdubova V. V. ${ }^{2}$, senior lecturer, varvara_tan@mail.ru \\ ${ }^{1}$ Institute of Applied Astronomy RAS, 10, Kutuzova Embankment, 191187, Saint Petersburg, Russia \\ ${ }^{2}$ Military Academy of Signal Corps, K-64, 3, Tikhoretsky prospect, 194064, Saint Petersburg, Russia
}

\begin{abstract}
This article describes the software package representing new math tests generator. The main features of our software are in the focus on creating a high-quality printed product and large variability of the generated tasks. That were achieved by using the $\mathrm{BT}_{\mathrm{E}} \mathrm{X}$ text processor and power of the Python language. Logically it consists of the control shell, the task parser, subject logic, formatting system and task database. The logic implements the set of abstractions that can be used in tasks (for example graphs, boolean functions, etc.). The task database exists in the form of JSON files with the specially created task formation language.

Currently, the most developed branch in task database is the discrete mathematics problems and abstractions. More than fifty types of tasks were implemented: operations on sets, representation of sets by Euler-Venn diagrams, algebra of sets, various ways of representing graphs, operations on graphs, some problems on graphs, representing Boolean functions in various ways, finding perfect forms, constructing and minimization using Karnaugh maps, Venn diagrams and hypercubes, analysis and synthesis of logic circuits.

The task generator can be used by a teacher when conducting practical and control classes, creating individual materials for the students. Tasks can be differentiated by the level of complexity when changing control parameters.

The generated tasks were used in education process for more than 1000 students of Military Academy of the Signal Corps and the improvement of mastering of discrete math was shown.
\end{abstract}

Keywords: discrete mathematics, education, set theory, graph theory, boolean algebra.

Citation: S. L. Kurdubov and V. V. Kurdubova, “Flexible Discrete Math offline Test Generator," Computer tools in education, no. 2, pp. 65-71, 2019; doi:10.32603/2071-2340-20192-65-71

\section{INTRODUCTION}

At the moment the discrete mathematics is extremely vital and demanded in the educational process of any technical University. Theoretical knowledge and problem solving skills of this subject area serve as the basis for the study of such disciplines as

- Digital circuits design,

- Industrial control system,

- Digital communications,

- Operations research et al. 
The discrete mathematics belongs to a relatively new field of knowledge and thus its educational and methodological supports are not enough. Almost no established methods of presentation of the material have been formed, the small number of study guides published in large editions are used in universities [1]. Most of the existing task books contains a relatively small number of tasks for each section. Therefore there are necessity of relevant task collection containing a large number of new and original tasks for high-quality organization and effective conduct of the educational process. It is important to note that in order to obtain high rates of training of students in such a subject area as discrete mathematics, in the educational process should be present the possibility of constant feedback teacher-student. Such a possibility can be provided by the Bank of individual tasks of different types and levels of complexity of a sufficiently large volume, covering all sections of the course under study with a quick check function.

\section{THE CONCEPT}

The special educational software was developed the main function of which is to assist students in the systematization and generalization of theoretical and practical knowledge in the main sections of discrete mathematics, enhance cognitive activity of students, a deeper study of the course.

The teacher can use the software in all types of training sessions, in preparation for classes, for the formation of didactic and handouts. With the software it is easy to form:

- individual practical tasks for verification and independent work,

— individual control works,

- individual packets of theoretical issues for the examination,

- mixed type individual tasks.

In order to speed up the task checking the teacher can use the tasks designed in the test form (with a choice of answers). It is also possible to use tasks of "open type" (without the proposed answers, but full answers will be generated for the teacher). Tasks can be differentiated by the level of difficulty.

In order to control the theoretical knowledge of students the teacher can create individual tickets from the basic concepts, theorems, properties and other theoretical provisions for a given arbitrary volume and complexity.

The quality of the printed tasks was achieved by using $\mathrm{AT}_{\mathrm{E}} \mathrm{X}$ text processor and different styling and alignment options for different tasks. The style of question/answer alignment depends on the actual content and requested spaces.

The abstractions implemented with the Python language allows the high level of variability of the same type generated tasks.

The task database exists in the form of JSON files with the specially created task formation language. Each JSON file contains fields which fully describe the task formulation and styling. The most complicated part is how to describe the incorrect answers or distractors [2] in such a way to correct answer was not obvious. There are three options in software:

- Task description contains four different question and four different answers. While being processed only one random question appears and distractors were compiled from correct answers to another three questions.

- Task description contains only one question and one correct answer. Distractors were calculated running task processing several times and collect results from another question realization. 
- Task description contains only one question, one correct answer and rule to calculate distractors.

\section{COVERED THEMES}

The tasks database covering the following sections of discrete mathematics:

- Set theory,

- Graph theory,

- Boolean algebra.

These sections are chosen because they are basic in the discipline and transitional in relation to the special professional disciplines studied further [4].

The "Set theory" subsection consists of more than 10 task types. There are traditional for this part of higher math:

- Set operators,

- Set relations,

- Representations with the Euler-Venn diagrams.

Also there are included the problems on the analysis of algebraic structures, boundaries of set theory and foundations of topology (algebras, monoids, semigroups).

The "Graph theory" subsection consists of more than 10 task types. There are most popular in applications tasks:

- local graph structure,

- graphs representations,

- graph operators,

- path on graphs, trees,

- optimization tasks.

The tasks presented in the subsection "Boolean functions" contain more than 30 types. Practice in this subsection brings students to an understanding of the principles of programmable logic chips, actively used in modern digital electronics. This subsection contains follows task types:

- construction of truth tables and value vectors for a Boolean function with an arbitrary number of variables and the number of operations on them

- normal forms,

- geometry representations with hypercube,

- minimization of boolean functions (Karnaugh maps, geometry, analytical Quine method),

- partialy defined functions,

- Zhegalkin polynomial, Pierce and Sheffer basis,

- analysis and synthesis of logic circuits.

\section{EXAMPLES}

\subsection{Euler-Venn diagrams}

1. Select the Euler-Venn diagram for the equation: $A \cap B \cup \bar{A} \cap \bar{B}$

1)

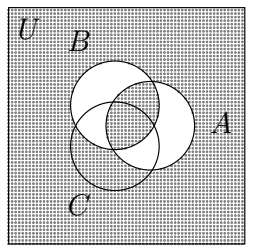

2)

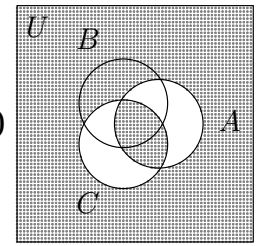

3)

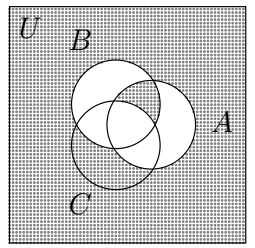

4)

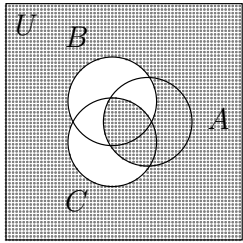


2. Let $x_{1}(u)=(u \in A), x_{2}(u)=(u \in B), x_{3}(u)=(u \in C)$ functionals $U \rightarrow\{0,1\}$, where $A, B, C-$ subsets of $U, u \in U$.

Select the Venn diagram for the partial boolean function $f\left(x_{1}, x_{2}, x_{3}\right)=(000-1---)$

1)

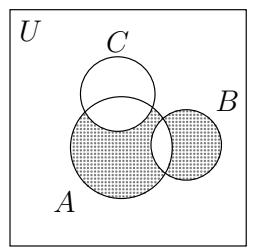

2)

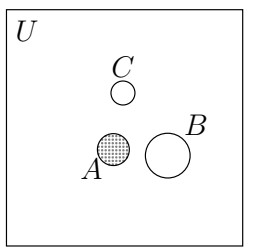

3)

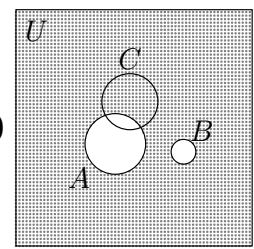

4)

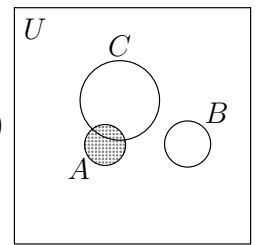

\subsection{Graph representation}

Select graph by the incidence matrix

$$
\left(\begin{array}{lllll}
1 & 0 & 0 & 1 & 0 \\
0 & 1 & 1 & 0 & 0 \\
0 & 0 & 1 & 0 & 1 \\
0 & 0 & 1 & 1 & 0 \\
0 & 0 & 0 & 1 & 1 \\
1 & 0 & 0 & 0 & 1
\end{array}\right)
$$

1)

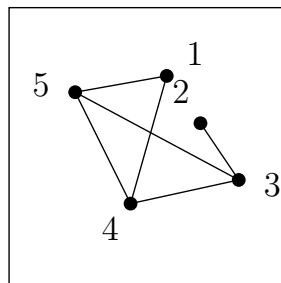

3)

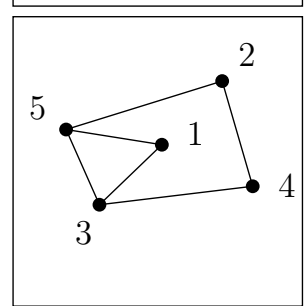

2)

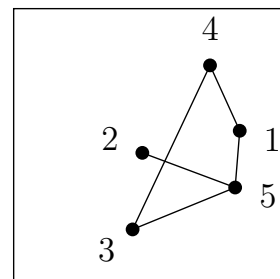

4)

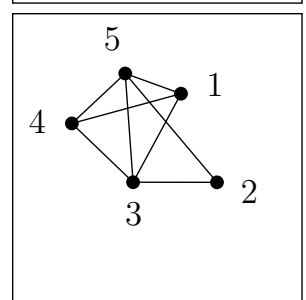

\subsection{Hypercubes}

Select the boolean function presented on the hupercube

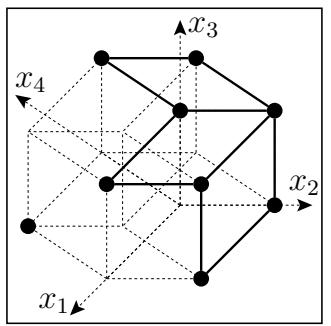

1) $x_{3} \bar{x}_{4} \vee x_{3} \bar{x}_{2} \vee x_{2} x_{4} \bar{x}_{3} \vee x_{2} \bar{x}_{3} \bar{x}_{1}$

2) $\bar{x}_{3} \bar{x}_{2} \vee \bar{x}_{1} \bar{x}_{4} \bar{x}_{2} \vee x_{1} x_{2} \bar{x}_{4} \vee x_{2} x_{4} \bar{x}_{1}$

3) $x_{3} \bar{x}_{4} \vee x_{3} \bar{x}_{1} \vee x_{1} x_{4} \bar{x}_{3} \bar{x}_{2} \vee x_{2} \bar{x}_{4}$

4) $x_{3} \bar{x}_{2} \vee x_{2} \bar{x}_{3} \vee x_{1} x_{4} \bar{x}_{3}$

\subsection{Karnaugh maps}

1. Select the minimal form for $f\left(x_{1}, x_{2}, x_{3}, x_{4}\right)$, using Karnaugh map

\begin{tabular}{|c|c|c|c|c|c|}
\hline & \multicolumn{4}{|c|}{$x_{3} x_{4}$} \\
\hline & & 00 & 01 & 11 & 10 \\
\hline \multirow{4}{*}{ 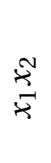 } & 00 & 0 & 0 & 0 & 0 \\
\hline & 01 & 0 & 0 & 0 & 0 \\
\hline & 11 & 0 & 1 & 1 & 1 \\
\hline & 10 & 0 & 0 & 0 & 0 \\
\hline
\end{tabular}

1) $x_{1} x_{3} \vee x_{1} \bar{x}_{4}$

2) $x_{1} \vee x_{3} \bar{x}_{4} \vee x_{2}$

3) $x_{1} x_{2} x_{4} \vee x_{1} x_{2} x_{3}$

4) $\bar{x}_{2} \vee \bar{x}_{1}$ 
2. For the function $f\left(x_{1}, x_{2}, x_{3}, x_{4}\right)=\left(\left(\bar{x}_{1} x_{2} \bar{x}_{3} x_{4}\right) \vee\left(\bar{x}_{1} x_{2} x_{3} \bar{x}_{4}\right) \vee\left(x_{1} \bar{x}_{2} \bar{x}_{3} \bar{x}_{4}\right) \vee\left(x_{1} \bar{x}_{2} \bar{x}_{3} x_{4}\right) \vee\right.$ $\left.\left(x_{1} \bar{x}_{2} x_{3} \bar{x}_{4}\right) \vee\left(x_{1} \bar{x}_{2} x_{3} x_{4}\right) \vee\left(x_{1} x_{2} \bar{x}_{3} \bar{x}_{4}\right) \vee\left(x_{1} x_{2} \bar{x}_{3} x_{4}\right)\right)$ select the Karnaugh map:

1)

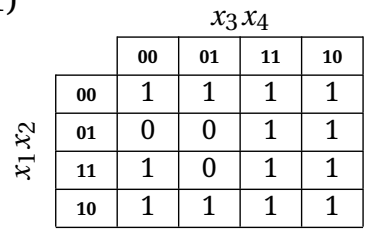

3)

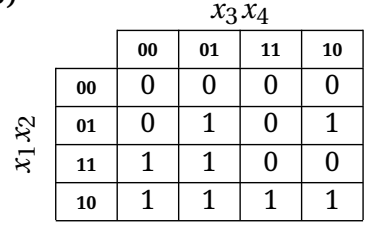

2)

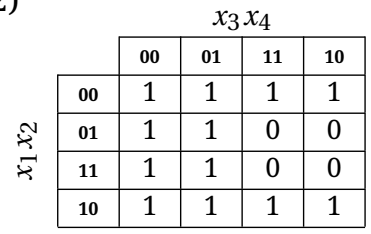

4)

\begin{tabular}{|c|c|c|c|c|c|}
\hline & \multicolumn{4}{|c|}{$x_{3} x_{4}$} \\
\hline & & 00 & 01 & 11 & 10 \\
\hline \multirow{4}{*}{$\underset{乛}{\widetilde{N}}$} & 00 & 1 & 1 & 0 & 0 \\
\hline & 01 & 1 & 0 & 0 & 1 \\
\hline & 11 & 0 & 0 & 0 & 0 \\
\hline & 10 & 0 & 0 & 1 & 1 \\
\hline
\end{tabular}

\subsection{Complete practice test and exam ticket}
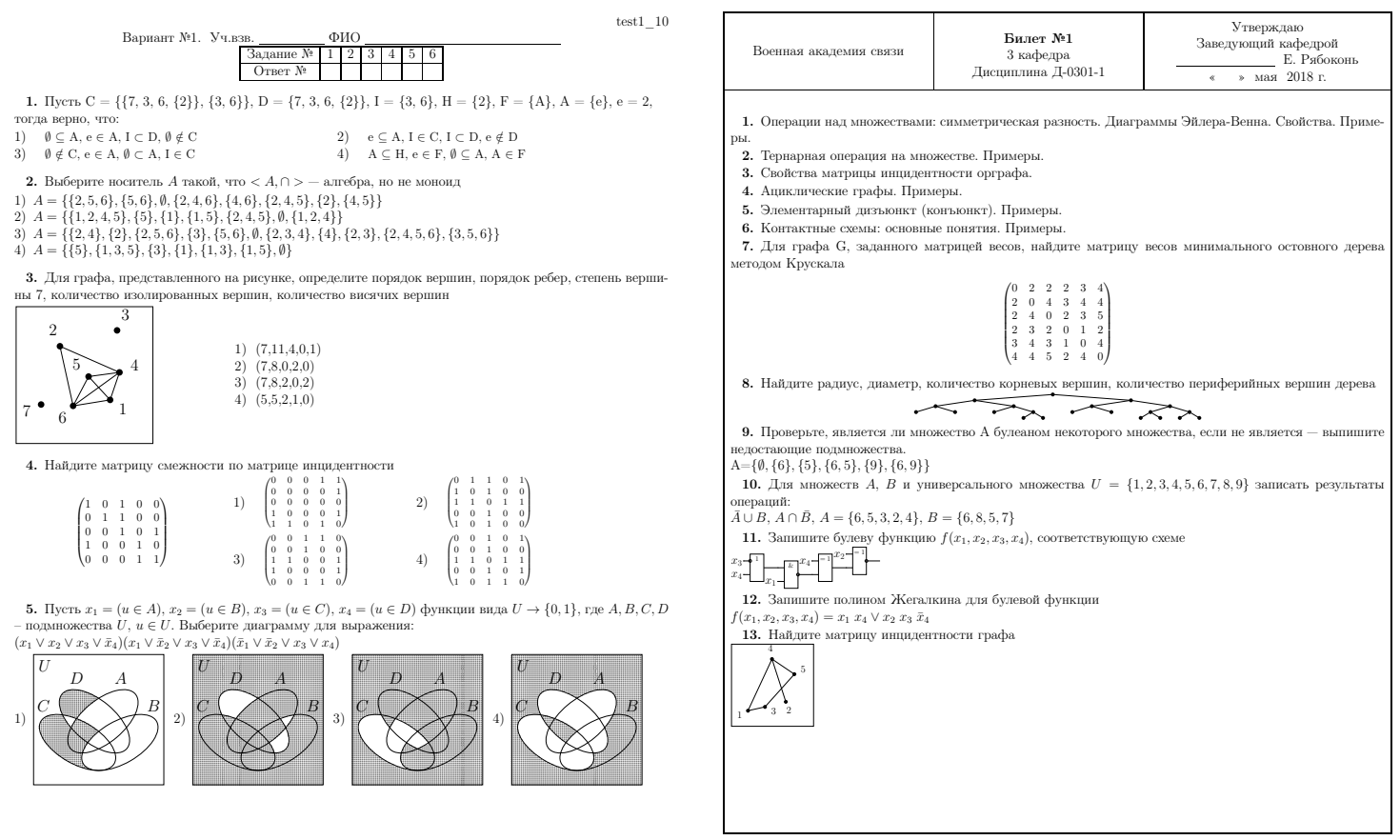

\subsection{Logic circuits}

Simplify the logic circuit:

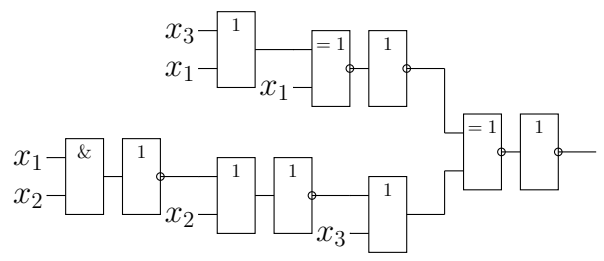
1) $x_{1} x_{3} \vee \bar{x}_{2} \vee \bar{x}_{3} \bar{x}_{1}$
2) $x_{2} \bar{x}_{1} \vee x_{1} \bar{x}_{2}$
3) $x_{1} \vee \bar{x}_{2} \vee x_{3}$
4) $x_{1} x_{3}$ 


\subsection{Basis}

Rewrite equation uses only the Peirce's arrow:

$f\left(x_{1}, x_{2}, x_{3}, x_{4}\right)=x_{1} x_{2} \vee x_{3}$
1) $\left(\left(x_{2} \downarrow x_{3}\right) \downarrow\left(x_{3} \downarrow x_{1}\right)\right)$
2) $\left(x_{1} \downarrow\left(\left(x_{1} \downarrow x_{2}\right) \downarrow x_{3}\right)\right)$
3) $\quad\left(\left(\left(x_{1} \downarrow x_{2}\right) \downarrow x_{1}\right) \downarrow x_{3}\right)$
4) $\left(\left(x_{2} \downarrow x_{3}\right) \downarrow\left(x_{2} \downarrow x_{3}\right)\right)$

\section{CONCLUSION}

The single set-theoretic approach was a distinctive feature when creating a Bank of tasks of the software. It can be traced in the selection and formulation of tasks in the sequence of submission of the material. The Bank contains more than sixty types of practical tasks on all topics of DM, each of which can be represented by an arbitrary number of different options in the test form of closed and open type.

We would like to draw attention to the task classes that allow to visualize the studied problem. These are tasks for the construction and analysis of Euler-Venn diagrams, tasks for the representation of graphs, analysis and synthesis of logic circuits, the geometric description of Boolean functions using the hypercube, the minimization on the hypercube and hypercube graphs. The problems of increased complexity include the proposed tasks on the representation of Boolean functions by Euler-Venn diagrams, the study of algebraic structures, the minimization of Boolean functions. The role of set theory in solving problems related to graph theory and Boolean functions is emphasized.

The using of presented software allows one to design a textbook that fully meets the requirements of the basic educational program, Federal state standard of higher education in the discipline of Mathematics, its composition, structure, and contents contains all the necessary evidence to identify him as a textbook providing the mathematical training of students in accordance with the provisions of training programs of different specializations. Testing of such a collection is held on the basis of MASC since 2017 [5]. The results of the ascertaining experiment, which was attended by more than 1,000 students, show an increase in the level of training and, last but not least, interest in the discipline with the introduction of generated material in the educational process.

\section{References}

1. A. Oxley, "Discrete Mathematics and its applications," Teaching Mathematics and its Applications, UK, vol. 29, no. 3, pp. 155--163, 2010; doi:10.1093/teamat/hrq007

2. D. Thissen, L. Steinberg, and A. R. Fitzpatrick, "Multiple-Choice Models: The Distractors Are Also Part of the Item,” Journal of Educational Measurement, vol. 26, no. 2, pp. 161-176, 1989; doi: 10.1111/j.17453984.1989.tb00326.x

3. J. Venn, "I. On the Diagrammatic and Mechanical Representation of Propositions and Reasonings,” Dublin Philosophical Magazine and Journal of Science, vol. 5, no. 10 (59), pp. 1-18, 1880; doi: 10.1080/14786448008626877

4. R. Haggarty, Discrete mathematics for computing, UK, 2002.

5. V. Tanuhina, S. Kurdubov, Collection of individual tasks in discrete mathematics, Russia, 2018 (in Russian).

Received 18.04.2019, the final version - 23.05.2019. 
Компьютерные инструменты в образовании, 2019

№ 2: 65-71

УДК: 519.688: 519.17

http://cte.eltech.ru

doi:10.32603/2071-2340-2019-2-65-71

\title{
Гибкий генератор автономных тестов по дискретной математике
}

\author{
Курдубов С. Л. ${ }^{1}$, кандидит физ.-мат. наук, старший научный сотрудник, \\ kurdubov@iaaras.ru \\ Курдубова В. В. ${ }^{2}$, старший преподаватель, varvara_tan@mail.ru \\ ${ }^{1}$ Институт прикладной астрономии РАН, наб. Кутузова, 10, 191187, Санкт-Петербург, Россия \\ ${ }^{2}$ Военная академия связи им. Маршала Советского Союза С. М. Буденного \\ K-64, Тихорецкий проспект, д. 3, 194064, Санкт-Петербург, Россия
}

\begin{abstract}
Аннотация
В данной статье описывается программный пакет, представляющий собой генератор новых математических тестов.

Основные особенности нашего пакета заключаются в ориентации на создание качественной печатной продукции и большой вариативности создаваемых задач, что достигается с помощью текстового процессора LATEX и мощностей языка Python. Пакет состоит из управляющей оболочки, синтаксического анализатора задач, предметной логики, системы форматирования и базы данных задач. Предметная логика представляет набор абстракций, которые могут быть использованы в задачах (например, графы, булевы функции и др.). База данных задач существует в виде JSONфайлов на специально созданным языке формирования задач.

На текущий момент в базе данных задач наиболее полно представлены задачи по дискретной математику. Было реализовано более пятидесяти видов задач по темам: операции над множествами, представление множеств диаграммами Эйлера-Венна, алгебра множеств, различные способы представления графов, операции над графами, некоторые задачи на графах, представление булевых функций различными способами, нахождение совершенных форм, построение и минимизация с помощью карт Карно, диаграмм Венна и гиперкубов, анализ и синтез логических схем.

Генератор задач может быть использован преподавателем при проведении практических и контрольных работ, создании индивидуальных материалов для учащихся. Задачи можно дифференцировать по уровню сложности путём изменения управляющих параметров.
\end{abstract}

Сформированные задания были использованы в учебном процессе для более чем 1000 студентов Военной академии связи имени С. М. Будённого, в результате чего наблюдалось улучшение усвоения дискретной математики.

Ключевые слова: дискретная математика, образование, теория множеств, теория графов, булева алгебра.

Цитирование: Курдубов С. Л., Курдубова В. В. Гибкий генератор автономных тестов по дискретной математике // Компьютерные инструменты в образовании. 2019. № 2. C. 65-71. doi: 10.32603/2071-2340-2019-2-65-71

Поступила в редакцию 18.04.2019, окончательный вариант - 23.05.2019. 